\section{ADDITIONAL RECORDS OF CANTOR'S LEAF-NOSED BAT HIPPOSIDEROS GALERITUS CANTOR, 1846 (MAMMALIA: CHIROPTERA: HIPPOSIDERIDAE) IN EASTERN INDIA: ODISHA}

\section{Subrat Debata ${ }^{1}$, Himanshu Shekhar Palei ${ }^{2}$, Pratyush Paradarsita Mohapatra ${ }^{3}$ \& Sharat Kumar Palita ${ }^{4}$}

${ }^{1,4}$ Centre for Biodiversity and Conservation of Natural Resources, Central University of Orissa, Koraput, Odisha 764020, India

2 Department of Population Management, Capture and Rehabilitation, Wildlife Institute of India, Post Box 18, Chandrabani, Dehradun, Uttarakhand 248001, India

${ }^{3}$ Department of Zoology, Government Science College, Chatrapur, Ganjam, Odisha 761020, India

${ }^{1}$ subrat.debata007@gmail.com, ${ }^{2}$ himanshu.palei@gmail.com ${ }^{3}$ pratyush.kingcobra@gmail.com, ${ }^{4}$ skpalita@gmail.com (corresponding author)

The Cantor's Leaf-nosed Bat Hipposideros galeritus Cantor, 1846 is one of the 81 species of leaf-nosed bats (Hipposideridae) found worldwide (Wilson \& Reeder 2005). It is widely distributed in South Asia and Southeast Asia (Francis et al. 2008) and has been recorded from Bangladesh, Borneo, Cambodia, India, Indonesia, Lao PDR, Malaysia, Sri Lanka, Thailand and Vietnam (Bates \& Harrison 1997; Molur et al. 2002). This species is categorized as 'Least Concern' in the IUCN Red List of Threatened Species (Francis et al. 2008). The species is mostly found in dry to wet lowland forests and prefers to roost inside old mines, cracks, culverts, crevices in old buildings, caves, among large boulders, overhanging ledges, tunnels, dungeons, forts, temples and churches (Bates \& Harrison 1997); sometimes co-roosting with

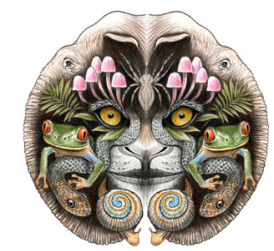

ISSN 0974-7907 (Online) ISSN 0974-7893 (Print)

\section{OPEN ACCESS} other bat species (Flannery 1995; Payne et al. 2005). It has been recorded from the sea level to an elevation of 1,100m (Molur et al. 2002).

Cantor's Leaf-nosed Bat is a comparatively rare species in India and has been recorded from a few localities with a small colony size (Bates \& Harrison 1997). It has been reported from Karnataka (Wroughton 1913; Brosset 1962), Gujarat (Ryley 1914; Wroughton 1918), Bihar (Wroughton 1915), Maharashtra (Brosset 1962), Madhya Pradesh (Khajuria 1970), and most recently from Andhra Pradesh (Srinivasulu 2004). Occurrence of this species in eastern India is very scarce and reported from only a single locality in Bihar (Wroughton 1915). So far 24 species of bats have been reported from Odisha, a coastal state of eastern India (Das et al. 1993; Debata et al. 2013). Here we present the first report on the occurrence of Cantor's Leaf-nosed Bat in Odisha and an additional distribution record in eastern India.

On 18 February 2012, while surveying the fauna of Bonai Forest Division in Sundergarh District, western Odisha, we observed a single individual of the species
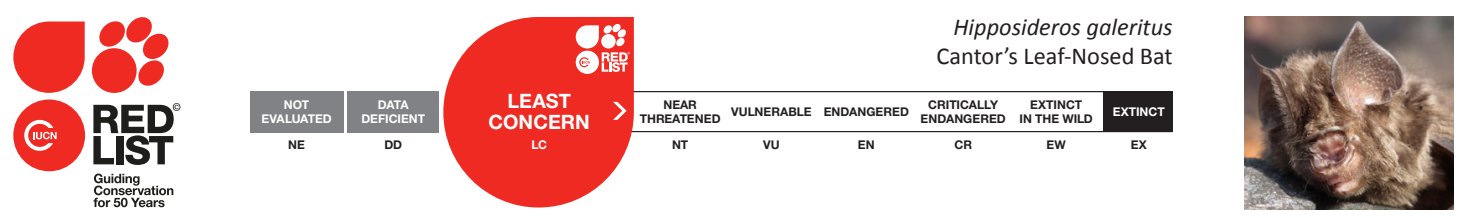

DOI: http://dx.doi.org/10.11609/JoTT.04247.7477-9 | ZooBank: urn:Isid:zoobank.org:pub:8A889D2D-1FB9-43DA-BFD0-F0C1560E0409

Editor: Sanjay Molur, ZOO/WILD, Coimbatore, India.

Date of publication: 26 June 2015 (online \& print)

Manuscript details: Ms \# 04247 | Received 05 March 2015 | Final received 21 May 2015 | Finally accepted 03 June 2015

Citation: Debata, S., H.S. Palei, P.P. Mohapatra \& S.K. Palita (2015). Additional records of Cantor's Leaf-Nosed Bat Hipposideros galeritus Cantor, 1846 (Mammalia: Chiroptera: Hipposideridae) in eastern India: Odisha. Journal of Threatened Taxa 7(8): 7477-7479; http://dx.doi.org/10.11609/JoTT.o4247.7477-9

Copyright: (C) Debata et al. 2015. Creative Commons Attribution 4.0 International License. JoTT allows unrestricted use of this article in any medium, reproduction and distribution by providing adequate credit to the authors and the source of publication.

Funding: Odisha Forestry Sector Development Project, Bhubaneswar.

Competing interests: The authors declare no competing interests.
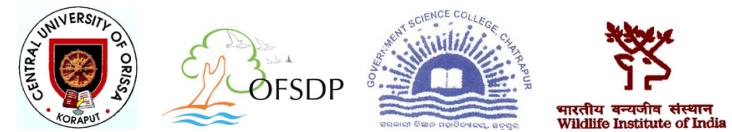

Acknowledgements: The authors are very thankful towards the Odisha Forestry Sector Development Project for providing financial assistance to carry out faunal surveys in Sundergarh District. The local communities of the survey areas also deserve thanks for taking us to bat roosting sites. We also acknowledge support of the students of the Centre for Biodiversity and Conservation of Natural Resources, Central University of Orissa for joining us in different field surveys in southern Odisha. 


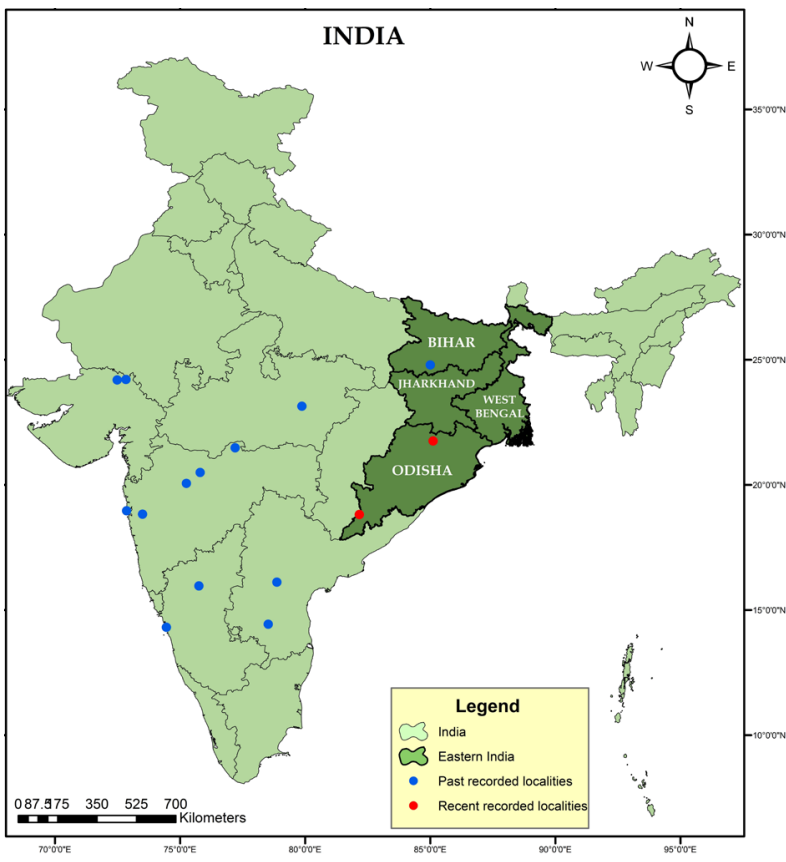

Figure 1. Map showing detailed recorded localities of Hipposideros galeritus in India

in a cave $\left(21^{\circ} 45^{\prime} 39.43^{\prime \prime} \mathrm{N} \& 85^{\circ} 06^{\prime} 50.01^{\prime \prime} \mathrm{E}\right)$ at the base of Khandadhar Waterfall at an elevation of $408 \mathrm{~m}$ (Fig. 1). Vegetation of the area comprises the northern tropical moist deciduous forest. During another occasion on 28 October 2014, while surveying bats in Koraput District, southern Odisha, we observed this species in a lime stone cave $\left(18^{\circ} 49^{\prime} 15.42^{\prime \prime} \mathrm{N} \& 82^{\circ} 10^{\prime} 0.21^{\prime \prime} \mathrm{E}\right.$; elevation $457 \mathrm{~m}$ ) at Gupteswar co-roosting with Hipposideros ater at a height of $3 \mathrm{~m}$ from ground (Fig. 1). Gupteswar lies within the Eastern Ghat hill range extensions in Odisha adjoining Kanger Valley National Park of the neighbouring state Chhatisgarh. Vegetation of the area is of mixed moist deciduous forest type.

This species is distinguished from other congeners in having dark brown pelage and nose leaf simple along with two pairs of well-developed supplementary lateral leaflets (Image 1). The anterior leaf has no median emargination whereas the intermediate leaf is simple with a slightly convex superior border. The posterior leaf is equipped with three well-developed septa dividing it into four distinct cells. The ears are triangular in shape being broad at the base. About two-third of the back of ears is covered with thick fur. Based on the above characters and the detailed external morphological measurements (Table 1), the species was confirmed as Hipposideros galeritus (Image 2) using the identification keys by Bates \& Harrison (1997) and Srinivasulu et al. (2010). No specimens were collected.

Occurrence of this microchiropteran species from

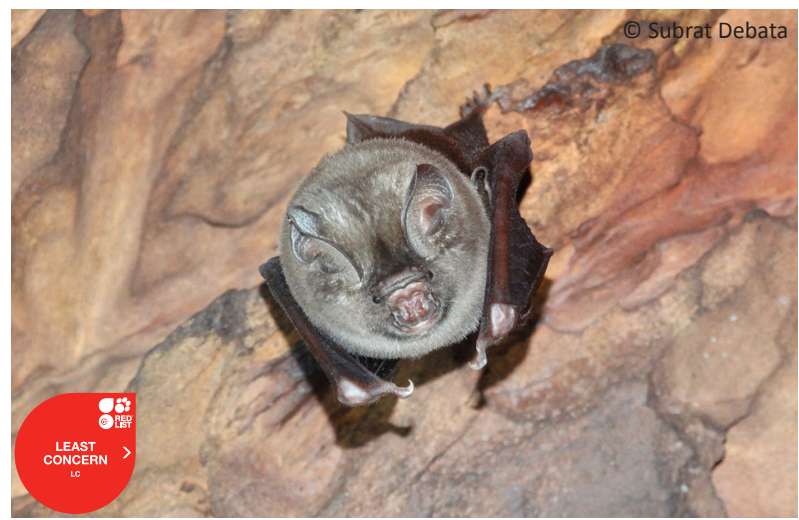

Image 1. Hipposideros galeritus from Gupteswar caves in Odisha

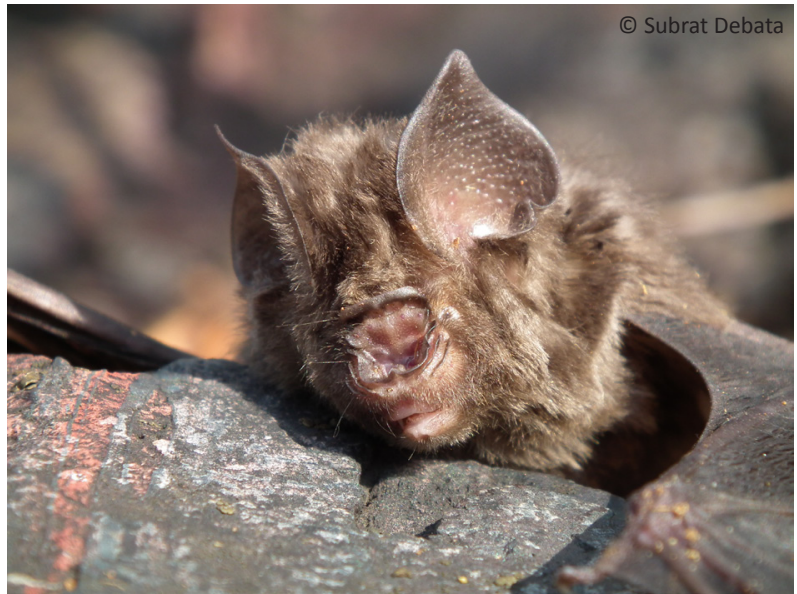

Image 2. Head of Hipposideros galeritus showing two pairs of supplymentary leaflets

Odisha has presumably been overlooked by previous workers. The lack of systematic surveys in many parts of Odisha and the Eastern Ghats has resulted in a biased understanding of distribution of many species across the Indian subcontinent, which is evident from the recent faunal inventories (Mohapatra et al. 2010, 2014; Agarwal et al. 2013; Debata et al. 2013; Palei 2014). In the present note herewith we are reporting occurrence of the species for the first time from Odisha from two localities namely Bonai and Gupteswar area with additional distribution records in eastern India. We recommend that the chiropteran diversity of Odisha be assessed, and targeted surveys be carried out for further inventories, particularly in the Eastern Ghats.

\section{References}

Agarwal, I., M. Wilkinson, P.P. Mohapatra, S.K. Dutta, V.B. Giri \& D.J. Gower (2013). The first teresomatan caecilian (Amphibia: Gymnophiona) from the Eastern Ghats of India-a new species of Gegeneophis Peters, 1880. Zootaxa 3693(4): 534 - 546; http:// dx.doi.org/10.11646/zootaxa.3693.4.7 
Table 1. Detailed morphological measurements of $\boldsymbol{H}$. galeritus

\begin{tabular}{|l|c|c|c|c|}
\hline \multirow{2}{*}{$\begin{array}{l}\text { External } \\
\text { characters }\end{array}$} & \multicolumn{2}{|c|}{$\begin{array}{c}\text { Morphological measurements of the three } \\
\text { individuals (in mm) (not collected) }\end{array}$} & $\begin{array}{c}\text { Average } \\
\text { length } \\
\text { (in mm) }\end{array}$ \\
\cline { 2 - 4 } & Khandadhar & Gupteswar & Gupteswar & 46.3 \\
\hline Forearm & 46 & 46.4 & 46.5 & 51 \\
\hline Head Body & 51 & 50.3 & 51.7 & 5.2 \\
\hline Hind foot & 5 & 5.3 & 5.3 & 31.6 \\
\hline Tail & 31.2 & 31.5 & 32.1 & 14.9 \\
\hline Ear & 15 & 14.4 & 15.3 & 35.9 \\
\hline $3^{\text {rd }} \mathrm{mt}$ & 35.8 & 35.7 & 36.2 & 35.3 \\
\hline $4^{\text {th }} \mathrm{mt}$ & 35.4 & 35.1 & 35.4 & 32.4 \\
\hline $5^{\text {th }} \mathrm{mt}$ & 31.9 & 32.3 & 33 & 14.1 \\
\hline $1 \mathrm{ph} 3^{\text {rd }} \mathrm{mt}$ & 14.2 & 14 & 14.1 & 19.2 \\
\hline $2 \mathrm{ph} 3^{\text {rd }} \mathrm{mt}$ & 19.1 & 19.2 & 19.3 & 10 \\
\hline $1 \mathrm{ph} 4^{\text {th }} \mathrm{mt}$ & 9.9 & 10.1 & 10 & 8.9 \\
\hline $2 \mathrm{ph} 4^{\text {th }} \mathrm{mt}$ & 9 & 8.8 & 8.9 & \\
\hline
\end{tabular}

Bates, P.J.J. \& D.L. Harrison (1997). Bats of the Indian Subcontinent Harrison Zoological Museum, Sevenoaks, England, UK, 258pp.

Brosset, A. (1962). The bats of central and western India - part II. Journal of the Bombay Natural History Society 59: 583-624.

Das, P.K., J.P. Lal \& V.C. Agrawal (1993). Mammalia, pp. 143-180. In: State Fauna Series I: Fauna of Orissa, Part 4. Zoological Survey of India, Calcutta.

Debata, S., H.S. Palei., P.P. Mohapatra \& A.K. Mishra (2013). First record of Lesser False Vampire Bat (Megaderma spasma, Linnaeus, 1758) from Sundergarh, Odisha, India. Small Mammal Mail 5(1): 26-27.

Flannery, T.F. (1995). Mammals of the South-West Pacific and Moluccan Islands. Comstock/Cornell, Ithaca, Ny, USA.
Francis, C., T. Kingston, M. Gumal, S. Bumrungsri, P. Banks, S. Molur \& C. Srinivasulu (2008). Hipposideros galeritus. In: The IUCN Red List of Threatened Species. Version 2014.3. <www.iucnredlist.org>. Downloaded on 06 February 2015.

Khajuria, H. (1970). A new leaf-nosed bat from central India. Mammalia 34: 622-627.

Mohapatra, P.P., A. Das \& S.K. Dutta (2010). Psammodynastes pulverulentus, range extension from Eastern Ghats, Andhra Pradesh. Herpetological Review 41(1): 111.

Mohapatra, P.P., H.S. Palei \& S.A. Hussain (2014). Occurrence of Asian Small-clawed Otter Aonyx cinereous (Illiger, 1815) in eastern India. Current Science 107(3): 367-370.

Palei, H.S. (2014). A first record of the Great Eared-Nightjar Lyncornis marcotis (Vigors, 1831) in Odisha, India. Journal of Threatened Taxa 6(12): 6566-6567; http://dx.doi.org/10.11609/JoTT.o3968.6566-7

Payne, J. \& C.M. Francis (2005). A Field Guide to the Mammals of Borneo. Sabah Society, Malaysia, 332pp.

Ryley, K.V. (1914). Report No. 12: Palanpur \& Mt. Abu, Bombay Natural History Society's Mammal Survey of India. Journal of Bombay Natural History Society 22(4): 684-699.

Srinivasulu, C. (2004). Cantor's Round Leaf Bat Hipposideros galeritus Cantor, 1846: An addition to chiropteran diversity of Andhra Pradesh, India. BAT NET-CCINSA Newsletter 5(1): 4-5.

Srinivasulu, C., P.A. Racey \& S. Mistry (2010). A key to the bats (Mammalia: Chiroptera) of South Asia. Journal of Threatened Taxa 2(7): 1001-1076; http://dx.doi.org/10.11609/JoTT.o2352.1001-76

Wilson, D.E \& D.M. Reeder (Eds). (2005). Mammal Species of The World. $3^{\text {rd }}$ Edition. Johns Hopkins University Press, Baltimore, MD. 2 Volumes: 2141pp.

Wroughton, R.C. (1913). Report No. 6: Kanara, Bombay Natural History Society's Mammal Survey of India. Journal of Bombay Natural History Society 22(1): 29-44.

Wroughton, R.C. (1915). Report No. 19: Bengal, Bihar \& Orissa, Bombay Natural History Society's Mammal Survey of India. Journal of the Bombay Natural History Society 24(1): 96-110.

Wroughton, R.C. (1918). Summary of the results from the Indian Mammal Survey - Part 1. Journal of the Bombay Natural History Society 25: 547-598. 